Journal of the Scholarship of Teaching and Learning, Vol. 21, No. 4, December 2021, pp. 69-88. doi: 10.14434/josotl.v21i4.32749

\title{
A Comic Road to Interiors, or the Pedagogical Matter of Gen Z Humor
}

\author{
Christopher J. Gilbert \\ Assumption University
}

\begin{abstract}
Generation Z (Gen Z) represents something of a quintessence for the broken promises that now seem to make up the promise of higher education. But if despair indicates the dark side of generational malaise around things like civic engagement, community, and student learning, the dark bumor that has emerged out of these generations points to modes of democratic citizenship that are more about reconciliation than resignation. This essay offers a critical reflection on Gen $Z$ bumor, its place in college and university classrooms, and its usefulness as a resource for reconsidering how teaching and learning might be tied to a comically examined life. It proceeds with a fresh look at pedagogies of hope as developed by Paulo Freire, Marth a C. Nussbaum, bell hooks, Henry A. Giroux, and others. This examination allows for the conceptualization of a comic poësis for understanding how instructional practices that meet students on uncommon ground contribute to the production, creation, and care for personbood as well as public culture. Ultimately, this essay balances theories of a comic teaching praxis with actual activities from the classroom to meditate on a pedagogy of reconciling curricula with who and where students are, beginning and ending with feedback loops.
\end{abstract}

Top of the world, but your world isn't real.

Your world's an ideal.

—Billie Eilish, "Therefore I Am”

Haiku, shmaiku, I can't

understand the intention

of reality.

-Jack Kerouac, Book of Haikus

Ah, bumor!

—bell hooks, Teaching Critical Thinking: Practical Wisdom

"Funny how I haven't hugged my best friends in six months," musician Billie Eilish intoned in an Instagram story from September 2020. "Funny."

A dark sense of humor pervades Eilish's lyricism and general disposition. It preceded the 2019 coronavirus (COVID-19) pandemic. Consider a meme that captures this sense of humor, along with the sentiments of Eilish's fans. The meme features a close-up of Joaquin Phoenix's portrayal of Joker from the film of the same name. Joker holds a cigarette to his mouth and looks askance as if in a Zenlike state. He is handcuffed and wearing a white jumpsuit, being interviewed by a therapist at the state hospital "after he has ostensibly murdered his mother, incited a riot, killed late night talk show host Murray] Franklin on live television, and escaped from police custody with the help of his throngs of clown-masked followers" (Floorwalker, 2019). Joker, also known as Arthur Fleck, has pseudobulbar affect, a condition that afflicts him with outbursts of ill-timed or misplaced laughter. He is laughing in the scene while remembering the mayhem in his head. "What's so funny?" the psychiatrist asks. He tells her he was thinking of a joke. "Do you want to tell it to me?" Joker smirks. "You wouldn't get it," he utters, before quietly crooning a few lines of Frank Sinatra's “That's Life" (Joker, 2019). Text above the close-up in the meme goads one to imagine a father "who has overcome money issues, 
depression, and alcoholism" asking his daughter "What's wrong?" The daughter, enacted by Joker, is said to have listened to just three seconds of a Billie Eilish song. "You wouldn't get it," reads the caption.

The early 2020s have been defined by moments of both selective confinement and collective stoppage, or interruption. Quarantines. Stay-at-home orders. Social distancing. Sheltering in place. Closures and re-openings. Cancellations. Cultural politics around safety measures like mask-wearing. Claims to individual liberties. Claims to the public good. COVID-19 case tracking maps. Hospitalizations. Death. Death shaming. Perhaps most importantly, pandemic times have been times for questioning schools of thought, and so for re-evaluating the highs and lows of civic (not to mention institutionalized) education. Much has been exposed about the political culture of the day vis-à-vis ecologies of public health in the educative practices of a generation afflicted. The meme above functions as something of a foil for precisely what Generation Z (Gen Z) has been attempting to do with its own comic approach to our beleaguered world.

Only time will tell what will come with a post-COVID return to "normalcy." It seems evident, though, that pandemic times have exposed the possibilities and failures of pedagogies that are driven by the cultivation of judgment as a crucial component of getting by when the promise of hope is outweighed by the prospect of despair. The humor of Gen Z-a generation marked by so many economic, political, and environmental conundrums, in addition to identity crises — stands out insofar as it comes off as a sort of humor of the oppressed. It laughs at (and laughs off) a hopefulness that appears best situated in a cultural lost and found. This humor resides in memes. It also suffuses absurd television shows and resounds in catchphrases like "OK, Boomer." What is more, the classroom has become something of a safe space for Gen Z humor and its cheerless spirit, especially since its modus operandi is a here and now that is sometimes outside the purview of higher education.

But let us back up a bit.

In times of crisis and moments of shared despair, comic matters almost always make their way to the fore. Humor managed to grow on the wrong side of paradise in what newsman Guy Hickok regularly observed to be the human comedy of the Lost Generation. Even the 1918 Spanish flu pandemic got "meme-ified" in jokes and other forms of public discourse (Foss, 2020). As Viktor Frankl (1959) famously put it, humor was a "soul's weapon in the fight for self-preservation" for those placed in concentration camps during World War II (p. 46). A comic spirit thrived soon after 9/11 even though it was pronounced dead. COVID-19 has prompted countless efforts for comic relief, with an all too familiar dark humor in comicality that tends to meld with calamities. The comic way is the way of at once humoring and locating the humor in "normal" ways of doing things. The comic way through calamity entails letting go of old ways, allowing uncertainty to creep in, and figuring out how to give permission for isolation or anguish or sufferance to pave a path to self-awareness and self-discovery. But the comic way can also constitute a rhetorical road away from the world, so to speak, and-for my part—-toward interiors.

My own scholarship on comedy and humor, and concomitant incorporation of it into my teaching, has led me to a provisional conclusion: pandemic times constitute a uniquely appropriate moment for the desperate comicality so characteristic of Gen Z. This comicality is nonsensical. It is absurd. It is strange. It does not just give off the feeling of a Dadaistic world but also a notion that the human condition is ever more unstable, ever more uncertain, and ever more unwelcome to the next generation. Nevertheless, as detachments and disconnections have introduced a greater sense of comic judgment in uncouplings within and beyond university classrooms, so have they forged spaces for reconsiderations of Martha C. Nussbaum's sense of cultivating humanity. I teach classes on rhetoric, communication, media, argument, persuasion, and humor. Whatever the class, students in the "Zoomer" generation regularly seek recourse in comical, or humorous, ways of grappling with broken cultural, economic, political, and most crucially educational promises. The comic art of coping

Journal of the Scholarship of Teaching and Learning, Vol. 21, No. 4, December 2021. josotl.indiana.edu 
is a matter of pedagogy and public judgment, of folly, and of solidarity in human being.

Here's the thing: if despair indicates the dark side of generational malaise around things like civic engagement, community, and higher education, the dark humor in comic judgment that has emerged out of Generation $Z$ points to reconciliation, not resignation. The purpose of this essay is therefore to consider how Gen $Z$ humor lays bare a comically examined life. I expand on and revise the view of what is widely regarded as a generational problem of despair alongside pedagogies of hope that have been conceptualized by Paul Freire, bell hooks, Henry A. Giroux, Nussbaum, and others. In so doing, I take seriously a sense of humor exemplified by Eilish's aesthetic in addition to the comic sensibility that comes along with it. Then, I turn to anecdotes and examples of Gen Z humor as it has materialized in my coursework and in the expressions of my students about what matters (or not). The essay concludes with some remarks on a comic examination of education for its possibilities and perversions, which I flesh out through a somewhat unexpected connection to Gen $\mathrm{Z}$ humor as the resource for tapping into a pedagogy of reconciling curricula with who and where students are, and what their own comic interiorities enable us to do in aligning educative ideals with lived experiences.

\section{A Generational Counsel of Despair}

Even before the pandemic, Millennials were lonely and dying deaths of despair (Ducharme, 2019). Those in Gen Z, by extension, have been doomed to lead lives of desperation (see Beilock, 2020; Berger, 2018; Chatterjee, 2018; \& Kwai \& Peltier, 2021). How? For so long, the Boomer generation promised a utopia. "Utopianism," as Nussbaum (2018) suggests, "is a forerunner of despair" (p. 215). As much is evident in the Gen Z axiom that "the struggle" is real. The promised land of opportunity in the U.S. has proven to be a false promise, and so has evinced an uncanny blend of dystopian fantasy (a preferred literary genre of Zoomers) with notions of social, political, and generational corruption. The simple point is that Gen Z is widely understood to be an "abandoned generation" (Giroux, 2006, p. 227; see also Petersen, 2020, p. x), convinced of a forlorn fait accompli and wary of any collective leap toward faith in the future.

This makes sense. There is eco-anxiety, mental illness, loneliness, and more. There is also a generalized counsel of despair, perhaps typified by the pop music icon Billie Eilish whose songwriting and aesthetic disposition are "darkly comic and casually morbid" (Rao, 2019). The dark comedy begins with her songs, many of the lyrics for which deal with mental health issues, psychic violence, social misgivings, sexual cageyness, lasciviousness, and a wholesale suspicion of power relations. These matters and more are folded into her self-described "weird" fashion sense and the seemingly unflappable nonchalance that comes along with it. Eilish is known for sporting voluminous, sometimes outlandish outfits, and coloring her hair with lambent dyes. Just as her music is a "borderless mishmash of content" (Enis, 2020), not unlike that found in memes on Instagram and TikTok, so is her demeanor variously sportive, arch, and even prankish albeit severe, seditious, and even gadfly-like. She is a mishmash unto herself_- "a sneaky jinn or a bored wallflower" who cannot bear to wither on the vine and so "writes what she sees" (St. Félix, 2019). Many of those in Gen Z are similarly ambivalent in their "confrontations of loss, fear, uncertainty, and death" (St. Félix, 2019). Simply, Eilish and her generational cohort were brought into being in a post-9/11 world and so are "intimately familiar with feelings of worry and instability on a macro level, having been born into a war that was broadcast live on television, and grown up in an echo chamber of very bad news" (Petrusich, 2019). Other wars have been televised. But, for Gen Z, the war of all against all is amplified. Many of my students are quick to say that Eilish is not the voice of a misfit generation; but she is $a$ generational voice (Margolis, 2019), with a Zen-like disposition that merges life and death, nihilism and humor. Here is how staff writer for Time, Raisa Bruner (2019), puts it:

Journal of the Scholarship of Teaching and Learning, Vol. 21, No. 4, December 2021. josotl.indiana.edu 
Part of Eilish's appeal as a Gen Z star is her attitude. In her music, she dwells on the macabre, from the strange fantasy of "Bellyache" - in which she sings from the perspective of a murderer - to the dark imagery of "Bury a Friend," which conjures a monster under her bed. In interviews and online, Eilish is frank when discussing her Tourette's syndrome and social issues she supports. Coming of age in a decade that can feel apocalyptic, she is attuned to the concept of a future on the brink.

If one imagines Gen Zers on the edge of an abyss, one can simultaneously fancy Eilish standing there with a wry smile on her face.

The point is not to dwell on Eilish here. Instead, it is to suggest that the aura of this so-called "catharsis queen" actually evokes a "we-centric attitude" (Seemiller \& Grace, 2016, p. 17), and thereby gives vision and voice to the structure of generational feeling that leaves Gen $\mathrm{Z}$ resigned to live and die by confusion and dejection, climate change, insecurity, and suicidal dreams (see Cliff, 2020; \& Mendez, 2020). These are hardly the makings of cultural politics for what lies ahead. On the contrary, they are the cultural politics of mock fun, turning boredom, pain, worry, fear, dismissal, and despair into resources for disconnected or diffused or otherwise digitally mediated empowerment (Grossberg, 1997, p. 20). More pressingly, they are the foundational principles of so many students in college and university classrooms. Thus, we have the "Memelord Generation" (Jepsen, 2019), making students Lords of the Meme with a dark sense of humor and yet a weird capacity to hope against hope.

Numerous scholars and practitioners have been urging such an ethos for decades now. Hope is the source for forward-thinking, teaching, and learning (Roberts, 2016), and the reason to struggle through oppression, discrimination, persecution, and certainly dis-ease. Hopelessness, writes Freire (1994) in Pedagogy of Hope, begets fatalism (p. 2). It belies the idea that learning is a struggle, through and through, which is why it is lifelong. Pedagogies of hope. Pedagogies of freedom. These are affirmative pedagogies. Despair, in the words of bell hooks (2003), is their "greatest threat" (p. 12). Like hopelessness, despair urges us away "from the concrete circumstances...we are experiencing right now" (hooks, 2003, p. 12), and tempts us into dispassion. Despair is the feeling of unwilling participants at best, willful objectors at worst (Jacobs, 2005, p. 793). Even worse is that it tends to fold disappointment and resignation and resentment into inertia of the imagination, or a sluggishness of the spirit. Hope — or what Giroux (2002) might call "educated hope"-is not only a reclamation of agency, but also a conduit for learning and appreciating community in the recognition of responsibilities we have to each other (p. 204). Pedagogies of hope help us pursue interventions that move beyond interpretation, and to seek alternative narratives to the mainstream while resisting the damaging impacts of the fanatical thinking that gets attached to prejudices of group membership based on racism, colonialism, bigotry, misogyny, and more. To hope is to make good. More importantly, to hope is to make public good on the promise of higher education. "It's hard to feel hope," though, says Eilish, "in a time that seems so utterly hopeless" (Seymour, 2020). What if education, too, feels hopeless?

Higher education today exists in a culture of job prospecting, civic disaffectedness, and economic disempowerment (Giroux, 2020). Students are cast as consumers. Colleges and universities, in Peter Seybold's (2014) terms, are "service stations," held captive to the market. If the imaginative visions of a proper higher education are realistic rather than romantic (Giroux, 2020), the promise of a degree is akin to unrequited romance. Those in Gen $\mathrm{Z}$ are largely despairing of the college experience not because of some bogus contract in the bargain of higher education, despite the "bitter heritage" of the Boomer generation (Schlesinger, 1949). Zoomers are despairing because this education is not set up to prepare them for a "real world" that is fundamentally "narcissistic and caters to the mood of widespread pessimism and the cathartic allure of the spectacle" (Giroux, 2020, p. 49). Or, as Cornel West put it in his 2017 convocation address for the Harvard Divinity School, higher education caters

Journal of the Scholarship of Teaching and Learning, Vol. 21, No. 4, December 2021. josotl.indiana.edu 
to the professional and managerial classes with degree programs that tend to supplant a "spiritual orientation" with market demands for "raw ambition and self-promotion." In The Monarchy of Fear (2018), Nussbaum laments that we are all confronted by "a world that we are not ready to cope with" (p. 19). Without a pedagogy of hope, we teach students little more than to deal with it.

But there is another way. A comic way.

\section{The Unbearable Lightness of Gen Z Humor}

I have always been surprised, even though I make various references to my own intellectual predilections and scholarship in the course of any semester, by students' attunement to my interest in humor. When I first taught ENG 389: The Rhetoric of American Humor in the spring of 2020, it was interrupted by COVID-19. Yet nearly every student enrolled in the class expressed to me after a semester of highs and lows just how vital it was for their learning. It was not just the course content. It was what the course enabled them to bring to bear in the learning process. From Freire through hooks to Giroux, we are told that the purpose of higher education is not to feel good. The point is to develop mental toughness and psychic resilience "in grappling with difficult material" (hooks, 1994, p. 154). Humor exemplifies a generational attitude that Eilish epitomizes in her use of lightness to counteract or comprehend dark matters, and way more so than that old maxim about misery and company. The organization of ENG 389 around rhetorical and cultural issues with humor spurred students to bring forth their own case studies, to struggle with them, and thereby to grapple with challenging principles of humorous content and comic spirits. In addition, it stirred them to live and work and be in a manner that both embraced and eschewed their own conventional wisdom that hope springs ephemeral.

The core learning objective of ENG 389 was to examine how humor makes (and is remade) by the culture of a day. Students read up on what Rebecca Krefting (2014) describes as the "laughscape" of humor in theory and in practice (p. 1). They applied a critical and curious eye to their lived conditions. They composed personal reflections on their senses of humor. They compiled keywords for humor a la Raymond Williams. They identified, analyzed, interpreted, and explained humor in situ. Most importantly, though, the twenty-two students and I took stock of U.S. American humor in the time of COVID-19 as it constitutes, or appears as the culmination of, a zeitgeist. In so doing, we shared the power in interrogating what Ira Schor (1987) calls the "actual circumstances" of something studied (p. 58). Humor, in other words, became a resource for affirming both the "system of attitudes and values that govern" the selection, organization, and evaluation of knowledge (Giroux, 1997, p. 16), and the raison d'être for student motivation. Our learning outcomes were diverse"some comic," in Shor's (1996) terms, "some inspiring, some bewildering, some frustrating" (p. 122). All reflected the spirit of our time.

Now, anyone who studies humor will be unsurprised to discover that there is a lively comic spirit in the "Age of Coronavirus." What struck me in the exemplars and critical examinations that my students showcased was the constancy in their rhetorical cultures of notably generational humor from before times to the springtime of stay-at-home orders, lockdowns, social distancing, toilet paper shortages, mask mandates, and quarantines. In other words, I was struck by a sense of humor that suggested how familiar the struggles of a pandemic seemed to be to a student body already riven by loneliness, isolation, mental illness, depression, anxiety, and disillusionment. The "meme culture" of Gen Z - a cohort of individuals who are digitally connected but materially detached-exemplifies a structure of generational feeling that anticipates a world of impending disappointment, if not doom, and yet displays a mode of "comic laughter" that revels in "fugitive, impure, disorienting occasions for buoyancy and even delight that transcend" the ostensive "madness of despair" (Gurewitch, 1994, p. 210; see also Mercado, 2019; Morina, 2019; \& Walen 2020). Gen Z students are pained. At times

Journal of the Scholarship of Teaching and Learning, Vol. 21, No. 4, December 2021. josotl.indiana.edu 
they are panicky and riddled with puzzlement. Sometimes hysterical. Nevertheless, the humor toward which they are inclined reveals no need for incongruities to be resolved or for comic judgments to make obvious sense of worldly absurdities.

There are many examples of Gen Z humor. They are legion on Adult Swim television shows, such as Rick and Morty, The Eric Andre Show, and Tim \& Eric's Bedtime Stories (Aroesti, 2019). More prominently, though, they are everywhere on Twitter, YouTube, and Instagram. TikTok especially is an archive for evidence of the "cultural logic" that propels Gen Z humor (Shifman, 2014a). Here's an example. There is a joke-like setup with the first line of text that reads, "Boomers: I hate my wife." The next line reads, "Millennials: I hate my life." Finally: "Gen Z: Hand over your money this is a strobbery." Beneath the text is a photoshopped image of a bright red strawberry appearing to wield a handgun. The iterations of this meme are countless. Many of them contain punch lines that characterize generational humor itself, with Boomer humor about hating wives, Millennial humor about hating lives, and Gen $\mathrm{Z}$ humor variously about traffic lights that look like penises, paper bags with laser eyes, a "Brocollie" (a dog with a huge head of Broccoli), a "Lemonk" (a monk with a lemon for a head), a plane bagel (you guessed it), and-you get the idea (Stopera, 2021). In September 2020, a user posted a collection of TikTok memes that carry these absurd, surrealist sentiments forward, but with the express notion that they "[make] depression laugh" (Visicks, 2020). This expression filters through coronavirus memes, from the generational quip that COVID-19 is a "Boomer Remover" to the internet archive of meme-maker efforts to "laugh away the apocalypse."1 Unsurprisingly, Eilish has inspired innumerable video memes that play on her song, "Bad Guy." There is a myriad of still shots and GIFs that use Eilish looking exasperated or simply befuddled, i.e., at the 2019 Grammys, to characterized life moods. To be sure, Eilish herself is known for her "funny responses to situations" (Mendez, 2020). So, it makes sense that these responses get incorporated into meme content. As one of my students might say, it takes a Zoomer to get the joke. And that's the joke: there is more to "get" out of Gen Z humor than in it.

Humor, for Zoomers, is a refuge (Walen, 2020). The blatant, absurd mergers that mess up what goes with what allow one nonsense to give "sense to another nonsense" (Heller, 2005, p. 149). They also yield to humor as the thing that makes sense, which is to say that Gen Z humor is not about figuring out the world; it is about coping with it. In a Freudian sense, memes-whether selfdeprecating, self-replicating, or simply projective-allow for a cathartic drift away from despair and toward utter folly. ${ }^{2}$ In memes, hard times become foolish. So do standards of judgment. So do fatalism and an ethos of amor fati. Memes let Zoomers go through life on their own, together. They give strange sense to a nonsensical world, in part by inciting the comic effect of upsetting the norm (Berger, 2014, p. 51). ${ }^{3}$ Consequently, Gen Z humor constitutes what Joseph W. Meeker (1997) might call the "comic way," or an art of living through the human condition by getting on, muddling through, putting up with, coming to terms, paddling one's own canoe, or bowling alone. This is what my students showed forth when they expressed the comic spirit of their generation's zeitgeist. Humor is a way to reconciliation without resignation such that alternative ways of making sense might be possible.

This all looks and feels and sounds a lot like the sort of hope that we as educators have long

\footnotetext{
1 "Laughing Away The Apocalypse With Coronavirus Memes" is a recurring series on Forbes with multiple parts curated by Abram Brown.

2 There is a rich tradition of comicality that emphasize this sensibility, including Søren Kierkegaard's belief that farce and jocosity can cure a sickness of the spirit, Mikhail Bakhtin's view of the carnivalesque, Gilles Deleuze's concept of the logic of (non)sense, and then again Arthur Asa Berger's more recent discussions of nonsense.

${ }^{3}$ Note the very real politics here of carving out a view of the world that allows for shared images and ideas about reality, and the influence they have on practical wisdom and everyday decision-making. Put differently, there is a thin line between comic takes and conspiracy theories, farce and false narratives, and education and evasion. This is partly why, as Giroux says, "educated hope" is as political as it is pedagogical.
}

Journal of the Scholarship of Teaching and Learning, Vol. 21, No. 4, December 2021. josotl.indiana.edu 
been urged to arouse. Humor, placed prominently in the classroom, inspired my students to intervene in world-making activities as "humor-actors" (Deleuze, 1990, p. 151) and therefore go beyond interpreting those activities (Freire, 1994, p. 91). Following Giroux (2020), it facilitated a public-facing approach to education, blending self-awareness with the recognition of others in acknowledgment of the agency that goes into futures yet to be made (p. 41). Agency here is a common burden (hooks, 2003 , p. 107). Or, in Freire's (1994) words, the very engagement with humor provoked "the tension between the denunciation of a present becoming more and more intolerable, and the 'annunciation,' announcement, of a future to be created, built" (p. 77). Attention to Gen Z humor, especially in pandemic times, recast students not as citizens in exile but rather as agents capable of seeing how their generational activities contribute to the educative process of revealing how and when conventional ways of doing and thinking and discoursing about things becomes oppressive. Memes in particular put the ostensive nonsensicality of Zoomer mindsets (i.e., their inner lives) on full display. They play around with images and ideas, upsetting standard notions of surfaces and depths, insides and outs.

The point is that Gen Z humor takes normal "assimilations" and "interiorizations" and flips their scripts so that interiors become exteriorized, and conventions become unassimilated (Freire, 1994, p. 56). Herein lies a way to hopeful pedagogies that position students and teachers as allies in comic judgment. COVID-19 has upset the order of things, but it has also exposed opportunities to reimagine student-teacher relationships in a manner that lets students lead the way. Hope is a condition of pedagogy. It is a byproduct of learning conditions as well. Gen Z humor has challenged me to reorient the very "pedagogies of comedic convention" (Berlant \& Ngai, 2017, p. 243). One outcome has been to make the pedagogical more comic and the comic more pedagogical. I have allowed myself to become like Lewis Carroll's fitful Gardener thinking he sees an Argument only to discover that it is mottled soap (Deleuze, 1990, p. 27). And I have come to recognize how much a comic pedagogy is far more rooted in an ethic of meeting students where they are than one of rooting out misapprehensions.

\section{Zen and the Comic Art of Pedagogy}

A comic pedagogy is grounded in, even revels in, worldly riddles. To channel a Kierkegaardian argot, it foments a laughter of despair, not from despair.

As I worked with my students and engaged with their sensibilities through so-called Gen Z humor, I witnessed the feeling that what is colloquially referred to as a fear of missing out is more akin to a shared despair about what is missed in the moment, when residues of the past are overlooked in the present. Memes are momentary. For Zoomers, though, they are also retrospective inasmuch as "moment after moment, representation after representation, dialogue after dialogue," they capture just how much Zoomers "memetically make their world" (Milner, 2016, p. 2). The ostensive nonsensicality in memes and the apparent frivolity in meme-making and meme-sharing are hardly about disengagement. These activities are suffused with comic spiritedness, accommodating different words, feelings, and images in the presentation of contradictions that can be taken in all at once, in their complexity and in their farcicality. How much weightier this can all be when considered along with Meeker's suggestion that comic moments such as these are mechanisms of survival. Comic moments bring the depths of the everyday to the surface. They turn insides out and bring what is outside even closer to home. In Gen Z humor, interiorities become exteriorities. Cut-and-dry solutions to problems get folded into the authenticity of felt moments of comic truth. Memes, in kind, constitute comically examined lives. There is a perceptible comic poësis in Gen Z humor.

The more these observations became clear in my ENG 389 course, the more I became inspired by my Gen Z students. And the more I came to a realization of my own regarding education in (and as) the art of rhetorical judgment on one hand and, on the other, problematizing modes of judging

Journal of the Scholarship of Teaching and Learning, Vol. 21, No. 4, December 2021. josotl.indiana.edu 
matters. Herein lies the medium for what I referred to above as an unexpected connection. It is between comic poësis and haiku. But before I go there, consider this sampling of student work for its engagement with the comic zeitgeist of pandemic times.

Memes get beyond jokes when they are seen for what one student described as the "different sides of the truth" that they put on display. Mockery in memes is about remaking misinformation and misfortune.

Memes do the most rhetorical work when they feature ridicule as a mechanism for calling out what is ridiculous. So many COVID-19 memes, writes a student, "point out the idiocy of some of the things that have been said and done" in response to the felt need for crisis management. Take a popular meme of "a doctor telling a man that his COVID-19 test came back positive," which makes fun of the phenomenon of hoarding certain home goods and personal care items by supposing the man to be incredulous given that "he has over 300 rolls of toilet paper." Here's another student example: a meme with people smoking Lysol vapes. As my students concluded, these and other memes provide a greater sense of order in chaos than doomsday preparation. Another student came to a similar conclusion in her own reference to a Twitter user tweeting: "Officials at @TheOnion have announced the website is shutting down citing the inability to be more ridiculous than actual events." To come to terms with a dire circumstance is to crack wise, and to acknowledge that it is the "world that is cracking up and that cracks us up-often without consent" (Davis, 2000, p. 3). Laughter reminds us of our humanity.

Meme culture is a milieu for comic relief. As one student put it, humor is a stress test that Gen Zers use "to release some of the tension we are feeling in such hard times." It is a resource "to work through serious issues, such as death, loss, and other heavy topics." TikTok in particular demonstrates how "shared laughter combines with satire to create a space where people feel comfortable sharing their admissions of helplessness against a larger American society through jokes and skits designed to make people laugh." Laughter is a happy act of reckless abandon, of being out of control. We laugh until we cry, writes another student, because of "our deeply rooted anxiety," for which-as another student suggests - memes are coping mechanisms. If relief is escapism, it is not a form of rhetorical retreat; it is a way of "escaping into the problem itself." Or, as yet another student proclaims, it is a way "to engage the very thing from which we find no escape." The only way out is in....

A final student example is relevant here. It is a meme with a picture of a doctor in close-up about to administer a nasal swab. Here is the text:

\section{GETTTING COVID TEST: \\ "YEAH... THIS MAY TICKLE A BIT." \\ POKES HYPOTHALMUS (sic)}

The text is composed in 5-7-5. It is an American haiku. Sure, the word "hypothalamus" is misspelled, and so the third line should actually be six syllables, but you get the point.

Even without this example, my own sudden turn to haiku is neither frivolous nor fanciful. To begin with, my wife and life partner wrote her undergraduate thesis on the Beat generation, and we have long shared an affinity for musings from Basho to Richard Wright and Jack Keroauc (more on them in a moment). I have used haikus for years, too, as a teaching tool to encourage students to articulate their thoughts and feelings, namely with that first-thought-best-thought Beat mentality.

So it is that I began to understand what Bruce David Russell (2003) calls the "pedagogical nature" of haiku, and the possibilities it affords for teaching and learning. So it is that I also began to appreciate the resonances of comic poësis in Gen Z humor, especially memes, and the educative value endemic to a spirit of living "poetically" (Leggo, 2005). Or better, comically. Like haikus, memes capture moments. Additionally, like a meme that is archived online and circulated freely, a haiku

Journal of the Scholarship of Teaching and Learning, Vol. 21, No. 4, December 2021. josotl.indiana.edu 
"allows any number of associations or interpretations," showing forth "like an exchangeable coin going from hand to hand, which everyone can use for his own purposes" (Ankersmit, 1993, p. 195). We can build on Conrad Hyers' (1996) view of a comic spirit to discern that haiku very often "offers certain little additions and subtractions, alterations, twists and turns, overstatements and understatements, curious coincidences, miscellaneous reports, gossipy asides, raised eyebrows, ironic observations, tongue-in-cheek interpretations, winkings and whisperings" (p. 3). These elements egged on a comic politics of posing questions without providing ready-made answers, much like haiku, much like an Eilish song, and so very much like Gen Z memes. Doubts about specifically U.S. American idealisms and promises and dreams defined the Beat generation, which is why its most recognizable writers worked moment to moment toward a reduction of the social and political and cultural sublime to the laughably absurd (Vogel, 2013). There is a crooked line from the Beats to the Boomers to the present-day Zoomers. More importantly, there is much to be grasped in what Kerouac once referred to as "a simple little picture in three little lines" (Rushdie, 2009, p. 87). There is so much complexity in the simplicity.

The entire haiku oeuvre of Kerouac almost anticipates Gen Z humor. ${ }^{4}$ As so many memes suggest, to cease to find humor in the everyday is to cease to live, if only for the moment. Kerouac's work exemplifies a similar orientation toward the comic relief in the haiku tradition. Many of his poems read as though they were composed by a man sitting like Buddha among mosquitos that know and care nothing of Nirvana. They therefore read like a senryu, which is a specifically comic haiku (or, baikai) that focuses on human folly by way of mockery and spoof. Basho certainly found humor in the human condition, with a haiku form "that embraced larger human and worldly concerns even as it retained comic roots" (Keene, 2011, p. 279). He located the ridiculous in the sublime. However, while Basho drank sake in the night with no moon, Kerouac awed at raindrops falling into his beer. While Basho saw the road as something to be traveled, Kerouac discovered in his time on the road that ways are things approaching us, narrowed as they are by received opinions and preconceived notions of the world. Basho accepted reality as it was, naturally, with something akin to comic resignation, and he represented it through a combination of observation and imagination (Takiguchi, n.d.; \& Shirane, 1998).

To a leg of a heron

Adding a long shank

Of a pheasant.

The caricature is as visible in the mind's eye as it is visible in the language.

The wind from Mt. Fuji

I put on the fan.

Here, the souvenir from Edo.

So trite, the pride of man. The karumi, or "lightness," of Basho's haiku exemplifies "the quality that detaches a man from worldly concerns while he is immersed in the mire, and that is precisely what makes humor possible" (Makoto, 1967, p. 169). Lightness like this allowed Basho (1996) to find humor

\footnotetext{
${ }^{4}$ It is beyond the scope of this essay to connect all the dots between the Beat Generation and Generation Z. But it is worth mentioning that Kerouac was among a generation of writers who cultivated a "haiku of confinement" that is similar in spirit to the sorts of comments on isolation, loneliness, and despair found in any number of Gen Z memes. Among those writers was Richard Wright, whose daughter described her father's use of haiku as a "self-nurturing" poíesis. See Benfey (2020), Hakutani (2007), Kiuchi (2018), and Wright (1998).
}

Journal of the Scholarship of Teaching and Learning, Vol. 21, No. 4, December 2021. josotl.indiana.edu 
in being chum for mosquitos during a night of sleeping in a tattered mosquito net. Still, although perhaps by extension, Kerouac (1998) saw reality through what he once called a "comedy of malice," or what Zoomers might conceive as a comedy of malaise - that kind of detachment that is, in fact, immersed in the very mire of worldliness. Narrow roads, for Basho, reveal life as it is. Kerouac's roads are narrowed by the confluence of beauty and ugliness, normalcy and strangeness, sense and nonsense. The comic form is fit to both the despair and the hope of experience.

Hence the fitness of Kerouac's haikus in grappling with troubling realities, and letting out exasperations and vexations.

Cool breeze-maybe

Just a shillyshallying show

That'll ruin everything

The uncertainty here resembles what Freud (1905) might call the "carpe diem" of an ordinary humorist (p. 104). In these terse lines is a "cynical joke" that disguises cynicism (Freud, 1905, p. 109). Comic reconciliation emerges out of the resignation to just be. A haiku like this does not simply capture the comicality of the world and nature, as with Basho's humorous wisdom. Everything in Kerouac's haiku "becomes exaggerated and distorted," and imbued with "absurdly stylized fantasy" (Cowan, 2010, p. 8).

Listen to the little bird sing!

All the little birds

Will die!

To reconcile here is to craft an image of disaster that melds with an imagined future wherein disaster might be averted. Disaster and hope. Creation and destruction. Moral codes. Societal constructs. The "natural" orders of things. All can be messed up. All can be made to seem nonsensical in the "comedy of survival," as Meeker (1997) calls it.

The earth winked

at me-right

In the john

Disconnections and attachments alike can be loosened or let loose in the haiku form.

Everywhere are these feedback loops between a comic approach to experience and the world out there. They underwrite Kerouac's “juxtaposition of incongruous elements” (Lambert, 2015) with what is right there before him and yet unattainable.

Well here I am,

2 PM-

What day is it?

To mark occasions. To keep track of the days. To be, in a phrase, "unstuck in time" (Vonnegut, 1969, p. 22).

Bee, why are you

staring at me?

I'm not a flower!

Journal of the Scholarship of Teaching and Learning, Vol. 21, No. 4, December 2021.

josotl.indiana.edu 
Like memes, these poetic communications are at once telegraphic and troublemaking (Shifman, 2014b). They stand out in Kerouac's talk of doomed birds and bathroom trips and mistaken identities, but also in his imaginations of "fallen stars," "juju beads on Zen manuals," "the parking lot of weeds," drunkards, Whippenpoofers, Bodhisattva relieving himself, lost perspectives of history amidst the cries of crickets and multivocal birds, et cetera. In one haiku, he writes:

I said a joke

under the stars

-No laughter

This could be a commentary on the silence of an absurd universe. Alternatively, it could be a reaction to those old prides and prejudices that carry forth from an ancient world, animated by a world that misses the punch lines. Today, this haiku feels like an encapsulation of those who do not "get" Gen Z humor. There is humor in Kerouac's haikus. There is humor in Basho's, too. But Kerouac typifies a comic tradition that interferes with interferences, and as such emphasizes collisions and confrontations and fumblings. To live and learn through this sort of comic poësis is to mess around with the traces of worldly, and perhaps even otherworldly, problematics.

All of this is to say that Gen Z humor actually prompted me to imagine how a combination of dark, absurd, nonsensical humor and poetic forms like haiku might enable my students and me to make sense-even scholarly sense-of the enduring problematics expressed in the fleeting meme. I see flashes of Kerouac in Gen Z humor. So many memes call out to a world that is anything but silent in its tendency to listen and either not respond or respond with clichés and bromides that have little purchase in an age of rampant capitalism, economic inequities, racial injustices, white supremacy, gun violence, and lately a pandemic. Student debt is not just financial; it is cultural. It entails a generalized milieu of misinformation and alternative truths. It entails a more specific set of feelings around the notion that there is a balance due from those in higher education (and elsewhere) who might come off as usurers. It entails deficiencies in a generational capacity for critical judgments that have been passed on and, incontrovertibly, passed off. Higher education should entail the creation, circulation, and care for agency such that students may "enlarge their perspective not only on the world but on their relationship to others and themselves" (França, 2019). The thing is, these sorts of enlargements are accessible in memes, and-when approached in terms of self-awareness, community orientations, and critical imagination - they turn the worldly work of krisis, of judgment, into the comic toil of reconciliation. Memes constitute a mechanism for cultural feedback. Looped into a curriculum that puts rhetorical cultures of humor front and center, i.e., my ENG 389 course, memes do more than separate generational preferences or sense from nonsense. They establish a site for fostering what Freire (1994) calls "kinship" between generations (p. 34), which is an essential impetus for a pedagogy of hope.

By mid-spring of 2020, the COVID-19 crisis was embedded in our lifeworlds. My classes had been remote since March. We broke for spring break and never saw each other again, except on screens. The moniker "Zoomers" took on new meaning as my students attended class via Zoom. In ENG 389, a sense of humor endured, and students responded to course materials much as they reacted to this most devastating of life's moments: through memes (Davis, 2020). Memes suffused final, metareflective papers that took stock of humor in the comic spirit of pandemic times. Inspired by the work of my students and by the pedagogical possibilities of "memeback" (Toulmin, 2017), I responded with a variation on my standard feedback memo. I responded with haikus.

Journal of the Scholarship of Teaching and Learning, Vol. 21, No. 4, December 2021. josotl.indiana.edu 


\section{Teaching as a Haiku Moment}

Feedback facilitates teachable moments. This is especially the case when it is timely and when students are part of the interactional process (and never more so than in online environments) (Darby \& Lang, 2019). Feedback allows teachers to engage with student learning in focused, meaningful ways. It allows us to meet students where they are. It enables us to goad student attention to critical mindsets and even provoke a feeling of mindfulness (Darby \& Lang, 2019, p. 132). Feedback, for me, has always been about a sense of Zen in the art of teaching and learning. It is about meditating on work done. It is about gleaning and sharing insights. It can be about transforming pedagogues into humorists, clowns, and fools, too, with haiku feedback for the Meme Generation as a "comic achievement" of such a transformation (Hyers, 1989, p. 15). Here's what I did.

I replaced feedback memos with haikus. After making jokes over the years about haikus and the value of pith over copia, I opted to utilize feedback as a teachable moment in the rhetorical act of critical engagement. A haiku, I told my students, is recognizable for its intensity of momentariness (i.e., the reading of student work) and its frankness of expression. Yet, much like memes, and much like Gen Z humor writ large, it betrays a certain openness. And it embodies the meme-like sensibility of those with a predilection to use humor as a resource for uniting generations and dealing with a dark age.

As noted above, my students ruminated on TikTok videos, late night television shows, and stand-up comedy with no audience. Mostly, though, they ruminated on memes. What follows is a sampling of my responses:

It was the middle

of the semester, and then

came the spring outbreak.

The joke is dead, long

live the joke! Memes help us cope

with mortality.

From the sublime to

the ridiculous is only

one pandemic.

Is this the real life?

COVID-19 rhapsody

says: carry on, carry....

In some cases the

cliché is true: laughter is

the best medicine.

Tick tock. The clock laughs

in the face of anyone

who stitches and saves.

Social media

is the comic frame for our

Journal of the Scholarship of Teaching and Learning, Vol. 21, No. 4, December 2021.

josotl.indiana.edu 
social distancing.

A comic response

to pandemos: no

overcorrection.

The funny meme spreads

like a disease when we let

laughter infect us.

So long, and thank you

for the meme. Now it is time

to wipe my rear end.

If you do not post

it, then it did not happen.

Thanks, Covidiots.

Coronavirus

panic at the comedy

shop. Wisdom. Folly.

The dark days are just

beginning, but we're charged with

a comic spirit.

Knock, knock. Who's there? Death.

Death who? The Angel of Dark

Humor. Look, and laugh.

One student who wrote about Tik'Tok memes and the hashtags that go along with them made some sage points about jests, building on the Latin root, gesta, which means an action or exploit. She took up comic feats of Gen Z folly by making a case about how TikTok provides a platform for a form of humor that mocks the messiness of the world by magnifying those who either attempt to clean it up or revel in it. Here are the four haikus I wrote in feedback.

Make your yesterday.

Now, the world can only be

known in short-form jest.

Today we laugh at

Funerals, and tomorrow

at pendulum swings.

It is time for a

daytime story just scary

enough for jokes. Once....

Journal of the Scholarship of Teaching and Learning, Vol. 21, No. 4, December 2021. 
Comedy is part

of the disease and part of

the cure. Oh, TikTok.

Within minutes of sending these haikus as a memo to one student, she responded by exclaiming that my comic response was her "favorite paper feedback." Another student, who wrote about memes regarding fake news, replied simply with this: "Beautifully spoken. Thank you." Other students expressed similar sentiments. I have since deployed haiku feedback in other classes. Here is one that reacts to a student's personal essay about a year of lockdowns.

Is it eagerness

or just an itch? Remote school.

Go to work for scratch.

The comic spirit comes with something of a kindred spiritedness when the self-referentiality that motivates Gen Z humor underwrites the feedback students get for their engagements with it.

What, then, to make of these verses in the context of hopeful pedagogies, and curricula for critical inquiries that seek to solve cultural and political problems, or at the very least deal with generational distress? First, haiku feedback allows for a stance that compels us to see itches as "imaginary, like the world" (Kerouac \& Ginsberg, 2010, p. 270). Scratch them. Don't scratch them. Imagination in observation, in awareness, in response. These are the things. Second, in the motivating factor for these verses is a potential resource for how we teach Gen Z students. My own predilection is to approach feedback (in formal responses to student work as well is in informal, formative responses to their thinking in incrementum) as a comic form of observation, interpretation, reaction, comment, assessment-judgment! But the hook is to enliven the classroom space and the culture that comes along with it so as to prevent it from becoming what Giroux (2014) dubs a "dead zone of the imagination." This is a hard truth to handle. It requires honesty and authenticity not unlike that found in the nonsense of Gen $\mathrm{Z}$ humor. And it became painfully clear during the shift to remote learning at the start of the pandemic and through the efforts to perpetuate higher education at a distance as the COVID-19 crisis continued. Most colleges and universities labored to figure out how to translate the so-called college experience into digital environments, and how to offer on-campus courses online. This required some reimaginations of coursework and community. By and large, though, these times have revealed "a fundamental lack of imagination in higher education," whereby teachers and students alike strive "to do what we've always done" (Craig, 2020). I can imagine a haiku by Kerouac about tilting at windmills. I can imagine a meme that riffs on backwards progress.

To place imagination at the center here is to acknowledge how the mind at work is precisely what allows for modes of civic engagement, agency, and action that resists self-interest, market demands, and cultural mandates. There are so many comic judgments about this feeling in Gen Z humor, with its absurdities, farcicalities, and fantastical wit and whimsy. Brought into the classroom, it brings out a sense of relief in release but also an opportunity to reconcile feelings "on the inside" with the toils of education. It provides students and teachers with a chance to mix what Freire calls "concrete feedback" about the opportunities and limitations in the real world with "counternarratives" in established feedback cycles (Shor, 1987, p. 58; see also Giroux, Lankshear, McLaren, \& Peters, 1996). Such reconciliation does not stand a chance because of the humor itself. Rather, it reveals a site to meet students where they are. It uncovers roads to interiors, to depths, by way of what is right there on the surface. According to Nussbaum (1997), higher education is about "learning how to be a human capable of love and imagination" (p. 14). I would amend this slightly to assert that it is about capacities for love and langhter. It is about a comic stretch of the imagination.

Journal of the Scholarship of Teaching and Learning, Vol. 21, No. 4, December 2021. josotl.indiana.edu 


\section{Conclusion, or Toward a Comic Stretch of the Pedagogical Imagination}

There is a Zen saying about continuing to climb when you get to the top of a mountain. For years now it has made me imagine Kerouac on Desolation Peak, gazing out from his tower while working as a fire lookout for the U.S. Forest Service in the mid-1950s, fathoming the glory of imperfect knowing. And Basho observing collapsing clouds on holy massifs. Gen Zers could be cast as presentday Desolation Angels, having cultivated a kind of humor that is at times dark and despairing and beyond comprehension, but hardly ever lacking in imagination. In haikus from his time on Desolation Peak, Kerouac (2003) wrote of awe-inspiring mountaintops-variously tortured by blue skies, "shrouded / In gray fog," and "done in" by clouds (p. 85). Yet these haikus bespeak a comic shift from resignation to reconciliation.

Throughout this reflection, I have reckoned with what it means to put humor at the center of academic study, in addition to everyday human comportment, in order to grapple with matters of teaching and learning that come up against generational disappointments with U.S. American promises. Gen $\mathrm{Z}$ humor offers a distorted mirror for seeing students in higher education today as civic beings trying to figure out how to cope and how to pull through. In this mirror is an image of malaise that shows forth a feeling that things might be better, might be different, if only there was something close to good faith in institutional or cultural change. I therefore want to conclude with a few thoughts about the intellectual resilience and affective survivalism that has marked my turn to haiku. More specifically, I want to ruminate on the comic stretch of my own imagination that has followed from an engagement with students where they are, which has brought to light a pedagogy of caring about what they care about and thereby reconciling course materials with the (comic) spirit they bring to educational spaces.

Pedagogies of care enable teachers and students to approach learning for its vast and varied connections to survival. As Jonna Mackin (2002) writes, a comic spirit is "essential to survival because of the particular way that it constructs the fantasy of a virtual self that survives domination and preserves sanity" (p. 201). The pedagogical sensibility imbued with a comic spirit urges us to focus on the experiences students bring to the classroom as resources for the very preparation we seek to provide in their development as citizens of the world. Gen Z humor yields immediate relevance. Humor is not a required element of either a comic spirit or a pedagogy of care. What matters is a careful pedagogy that fosters learning opportunities in explorations of student experiences that filter more into humane public judgments than, say, career paths. It just so happens that Gen $\mathrm{Z}$ humor, as it appears in TikTok videos and various memes, captures generational experience in a way that lends itself to diverse perspectives as foundations for teaching and learning. The comedy of survival in this setup relies on the complication of simple truths.

By extension, then, a pedagogy that cares more about reconciliation than either resignation to standard ways of doing things or to a stock of standard judgments about emancipation and oppression makes "higher" education student-centered by making it human-centered. The widely publicized mental health of Gen Zers is enough to give us pause about the ancient belief that education is nothing if it is not rooted in mind and body. Even before the isolation that came with pandemic times Gen Z was dubbed the Loneliest Generation. This makes sense when worldly living is represented as survival of the fittest. We can challenge this arrangement by recasting classrooms as "we" spaces wherein students are encouraged to grapple with our curricula through pedagogies that lead them to get out of their comfort zones. Civic being is human being. This is a virtual truism for critical pedagogues. As Freire reminds us, it is crucial that we work together with students to "read the world" (Freire \& Macedo, 1987, p. 29), and so to collaborate in judging matters of mutual concern to "us" and "them."

My own humor class provoked me to reimagine how the actual, authentic cultural productions of students figure in to course content and pedagogical praxis. There and elsewhere, it has led me to

Journal of the Scholarship of Teaching and Learning, Vol. 21, No. 4, December 2021. josotl.indiana.edu 
introduce participative modes of assessment that prioritize engagements-which is to say reconciliations - over examinations. Assessments are vital when it comes to the display of learning. Shared investments in assessments, though, should begin with shared investments in self-awareness. This goes for students and teachers alike. Changes in classroom dynamics therefore follow from changes to instructional design, which in turn bring about changes to what is "critical" in our pedagogies, and what is not. Perhaps we change how we respond to student assessments. Perhaps we emphasize experience-based learning (not to be confused with experiential learning, i.e., community service). Perhaps we base our course materials on student learning that is activated by inquiries into their own experiences. Perhaps we reimagine what hope looks like as part and parcel of pedagogy. Perhaps we have our students pause to reflect on learning opportunities more often as haiku moments.

Hope requires a comic spirit. This is what we can learn from Gen Zers. So many scholars and pedagogues have espoused a view of hope that is tied to various human conditions: grief, fear, anger, hatred, humility, gratitude, and more. I would add to this list an element of good humor. There is a sentiment espoused by Japhy in The Dharma Bums when he laments that "nobody thinks of crap anymore" (Kerouac, 1976, p. 39). It echoes a haiku in which Kerouac (2003) finds himself "Looking up at the stars" and "Going tsk tsk tsk" (p. 18). What is more, it resounds in the glut of TikTok compilations to watch on the toilet, and in the reimagined "toilet humor" that resonated in a meme about real life in the early days of the COVID-19 crisis. The meme parlayed a poetic quality that mimicked lyrics from the Bon Jovi song "Livin' on a Prayer" in order to reckon with the toilet paper shortage. The chorus of "Livin' on a Prayer" goes like this: 'Whoa, we're halfway there / Whoa, livin' on a prayer." The meme features a black background. At the top of the frame is the line, "Whoa, I'm halfway there." It appears above a roll of toilet paper partly opened out. Just below it is the line, "Whoa, livin' on a square," which sits above a single ply.

Hope mingles with despair in this meme. It has a message about the comedy of survival, about being in it together. "It's about humanization," bell hooks might say (Yancy \& hooks, 2015). From my vantage, it's about the comic imagination that propels this meme's rhetorical force.

Ah, Gen Z humor!

\section{References}

Ankersmit, F. R. (1993). Metaphor in political theory. In F. R. Ankersmit \& J. J. A. Mooij (Eds.), Knowledge and language (pp. 155-202). Springer, Dordrecht.

Aroesti, R. (2019, August 13). "Horrifyingly absurd": How did millennial comedy get so surreal? The Guardian. Retrieved from https://www.theguardian.com/tv-and-radio/2019/aug/13/howdid-millennial-comedy-get-so-surreal

Basho, M. (1996). Basho's narrow road: Spring and autumn passages (H. Sato, Trans.). Stone Bridge Press. Beilock, S. L. (2020, July 27). Why young Americans are lonely. Scientific American. Retrieved from https://www.scientificamerican.com/article/why-young-americans-are-lonely/

Benfey, C. (2020, June 25). Richard Wright, Masaoka Shiki, and the haiku of confinement. The New York Review of Books. Retrieved from https://www.nybooks.com/daily/2020/06/25/richardwright-masaoka-shiki-and-the-haiku-of-confinement/

Berger, A. A. (1998). Absurdity, confusion, and nonsense (logic). In An Anatomy of Humor (pp. 1820). Transaction Publishers.

Berger, P. L. (2014). Redeeming laughter: The comic dimension of human experience (2nd ed.). De Gruyter.

Berger, S. (2018, May 14). Gen $z$ is the loneliest generation, survey reveals, but working can help. CNBC. Retrieved from https://www.cnbc.com/2018/05/02/cigna-study-loneliness-is-anepidemic-gen-z-is-the-worst-off.html

Journal of the Scholarship of Teaching and Learning, Vol. 21, No. 4, December 2021. josotl.indiana.edu 
Gilbert

Berlant, L., \& Ngai, S. (2017). Comedy has issues. Critical Inquiry, 43(2), 233-249. https://doi.org/10.1086/689666

Bruner, R. (2019, March 29). Billie Eilish is 17, but her music is for grownups too. Time. Retrieved from https:/ time.com/5560210/billie-eilish-debut-album-review/

Chatterjee, R. (2018, May 1). Americans are a lonely lot, and young people bear the heaviest burden. NPR. Retrieved from https://www.npr.org/sections/health-

shots/2018/05/01/606588504/americans-are-a-lonely-lot-and-young-people-bear-theheaviest-burden

Cliff, A. (2020, January 27). Catharsis queen: How Billie Eilish became the voice of gen z-and the Grammys. The Guardian. Retrieved from https://www.theguardian.com/music/2020/jan/27/billie-eilish-gen-z-grammys

Craig, R. (2020, September 4). Colleges should go back to school on remote learning. Inside Higher Ed. Retrieved from https://www.insidehighered.com/views/2020/09/04/have-collegesseized-or-missed-opportunity-improve-remote-learning-opinion

Darby, F., \& Lang, J. M. (2019). Small teaching online: Applying learning science in online classes. Jossey-Bass.

Davis, D. D. (2000). Breaking up [at] totality: A rhetoric of laughter. Carbondale, IL: Southern Illinois University Press.

Davis, D-M. (2020, May 6). 72\% of gen zers say coronavirus memes make them feel "capable of getting through this.” Business Insider. Retrieved from https://www.businessinsider.com/genz-says-coronavirus-memes-help-them-get-through-pandemic-2020-5

Deleuze, G. (1990). The logic of sense (M. Lester, Trans.). Columbia University Press.

Ducharme, J. (2019, June 13). More millennials are dying 'deaths of despair,' as overdose and suicide rates climb. Time. Retrieved from https://time.com/5606411/millennials-deaths-of-despair/

Enis, E. (2020, April 2). Millennial culture isn't youth culture anymore. Vice. Retrieved from https://www.vice.com/en/article/4agmmw/millennial-culture-isnt-youth-culture-anymore

Floorwalker, M. (2019, October 8). Joker director finally explains crucial last scene. Looper. Retrieved from https://www.looper.com/169166/joker-director-finally-explains-that-last-crucialscene/.

Foss, K. A. (2020, July 31). How the 1918 pandemic got meme-ified in jokes, songs and poems. Smithsonian Magazine. Retrieved from https://www.smithsonianmag.com/history/memes1918-pandemic-180975452/

França, J. (2019, July 2). Henry Giroux: "Those arguing that education should be neutral are really arguing for a version of education in which nobody is accountable." CCCBLAB. Retrieved from https://lab.cccb.org/en/henry-giroux-those-arguing-that-education-should-be-neutralare-really-arguing-for-a-version-of-education-in-which-nobody-is-accountable/

Frankl, V. E. (1959, 2006). Man's search for meaning: An introduction to logotherapy. Beacon Press. Freire, P. (1994). Pedagogy of hope: Reliving pedagogy of the oppressed (R. R. Barr). Bloomsbury. Freire, P., \& Macedo, D. (1987). Literacy: Reading the word and the world. Bergin \& Garvey.

Freud, S. (1905, 2002). The joke and its relation to the unconscious (J. Crick, Trans.). Penguin Books.

Gifford, T. (2017). The environmental humanities and the pastoral tradition. In C. Schleiphake (Ed.), Ecocriticism, ecology, and the cultures of antiquity (pp. 159-174). Lexington Books.

Giroux, H. A. (1997). Schooling and the culture of positivism: Notes on the death of history. In Pedagogy and the politics of hope: Theory, culture, and schooling. Routledge.

Giroux, H. A. (2002). Educated hope in an age of privatized visions. Cultural Studies - Critical Methodologies, 2(1), 93-112. https://doi.org/10.1177/153270860200200111

Giroux, H. A. (2005). Schooling and the struggle for public life: Democracy's promise and education's challenge (2nd ed.). Routledge.

Journal of the Scholarship of Teaching and Learning, Vol. 21, No. 4, December 2021. josotl.indiana.edu 
Gilbert

Giroux, H. A. (2006). America on the edge: Henry Giroux on politics, culture, and education. Palgrave MacMillan.

Giroux, H. A. (2014). When schools become dead zones of the imagination: A critical pedagogy manifesto. Policy Futures in Education, 12(4), 491-99. https://doi.org/10.2304/pfie.2014.12.4.491

Giroux, H. A. (2020). Neoliberalism's war on higher education. Haymarket Books.

Giroux, H. A., Lankshear, C., McLaren, P., \& Peters, M. (Eds.). (1996). Counternarratives: Cultural studies and critical pedagogies in postmodern spaces. Routledge.

Grossberg, L. (1997). Introduction: Re-placing the popular. In Dancing in spite of myself: Essays on popular culture (pp. 1-28). Duke University Press.

Gurewitch, M. (1994). The ironic temper and the comic imagination. Wayne State University Press.

Hakutani, Y. (2007). Richard Wright's haiku, zen, and the African "primal outlook upon life." Modern Philology, 104(4), 510-28. https://doi.org/10.1086/519191

Heller, A. (2005). The immortal comedy: The comic phenomenon in art, literature, and life. Lexington Books.

hooks, b. (1994). Teaching to transgress: Education as the practice of freedom. Routledge.

hooks, b. (2003). Teaching community: A pedagogy of hope. Routledge.

Hyers, C. (1989). The langhing Buddha: Zen and the comic spirit. Wipf \& Stock.

Hyers, C. (1996). The spirituality of comedy: Comic heroism in a tragic world. Transaction Publishers.

Jacobs, D. (2005). What's hope got to do with it? Toward a theory of hope and pedagogy. JAC, 25(4), 783-802. Retrieved from https://www.jstor.org/stable/20866715

Jepsen, C. (2019, July 16). Why you should be focused on gen- $z$ and stop talking about millennials. Medium. Retrieved from https://medium.com/swlh/why-you-should-be-focused-on-gen-zand-stop-talking-about-millennials-af3a7ede1187

Joker. Directed by Todd Phillips, performances by Joaquin Phoenix and Robert De Niro, Warner Bros. Pictures, 2019.

Keene, D. (2011). Matsuo Basho. In Wm. T. de Bary (Ed.), Finding wisdom in east Asian classics (pp. 287-300). Columbia University Press.

Kerouac, J. (1976). The dharma bums. Penguin Books.

Kerouac, J. (1998, June 22). On the road again. The New Yorker. Retrieved from https://www.newyorker.com/magazine/1998/06/22/on-the-road-again-jack-kerouac

Kerouac, J. (2003). Book of haikus. R. Weinreich (Ed.). Penguin Books.

Kerouac, J., \& Ginsberg, A. (2010). The letters. B. Morgan \& D. Stanford (Eds.). Viking.

Kiuchi, T. (Ed.). (2018). American baiku: New readings. Lexington Books.

Krefting, R. (2014). All joking aside: American humor and its discontents. Johns Hopkins University Press.

Kwai, I., \& Peltier, E. (2021, April 15). “What's the point?” Young people's despair deepens as Covid-19 crisis drags on. The New York Times. Retrieved from https://www.nytimes.com/2021/02/14/world/europe/youth-mental-health-covid.html

Lambert, N. L. (2015, June 15). Jack Kerouac's American haiku. Humor in America. Retrieved from https://humorinamerica.wordpress.com/2015/06/15/jack-kerouacs-american-haiku/

Leggo, C. (2005). The heart of pedagogy: On poetic knowing and living. Teachers and Teaching, 11(5), 439-55. https://doi.org/10.1080/13450600500238436

Mackin, J. (2002). Trickster-outlaws and the comedy of survival. In G. Harper (Ed.), Comedy, fantasy and colonialism (pp. 189-204). Continuum.

Makoto, U. (1967). Literary and art theories in Japan. Press of Western Reserve University.

Margolis, E. (2019, August 1). Will Billie Eilish prove to be the most important pop star of our generation? Vogue. Retrieved from https://www.vogue.co.uk/article/billie-eilish-is-theultimate-gen-z-role-model

Meeker, J. W. (1997). The comedy of survival: Literary ecology and a play ethic. University of Arizona Press.

Journal of the Scholarship of Teaching and Learning, Vol. 21, No. 4, December 2021.

josotl.indiana.edu 
Gilbert

Mendez, M. (2020, April 2). 20 Billie Eilish memes that perfectly capture your dark sense of humor. Elite Daily. Retrieved from https://www.elitedaily.com/p/20-billie-eilish-memes-thatperfectly-capture-your-dark-sense-of-humor-22666765

Mercado, W. (2019, June 17). The shocking and absurdist humor of gen z. Medium. Retrieved from https://medium.com/@williamfmercado/the-shocking-and-absurdist-humor-of-gen-zf3d6e $363 \mathrm{~d} 42 \mathrm{~b}$

Milner, R. M. (2016). The world made meme. MIT Press.

Morina, P. (2019, August 13). Dear millennials and gen z, history won't find your humor funny and neither will you. Medium. Retrieved from https://medium.com/invisible-illness/dearmillennials-and-gen-z-history-wont-find-your-humor-funny-and-either-will-you9553ff30bfac

Nussbaum, M. C. (1997). Cultivating humanity: A classical defense of reform in liberal education. Harvard University Press.

Nussbaum, M. C. (2018). The monarchy of fear: A philosopher looks as our political crisis. Simon \& Schuster.

Petersen, A. H. (2020). Can't even: How millennials became the burnout generation. Houghton Mifflin Harcourt.

Petrusich, A. (2019, August 23). The loneliest generation embraces Billie Eilish. The New Yorker. Retrieved from https://www.newyorker.com/culture/cultural-comment/the-loneliestgeneration-embraces-billie-eilish

Rao, S. (2019, April 8). Billie Eilish's casually morbid music defined gen z. Now she has a no. 1 billboard debut. The $W$ ashington Post. Retrieved from https://www.washingtonpost.com/artsentertainment/2019/04/08/billie-eilishs-casually-morbid-music-defined-gen-z-now-she-hasno-billboard-debut/

Roberts, P. (2016). Happiness, hope, and despair: Retbinking the role of education. Peter Lang.

Rushdie, S. (Ed.). (2009). The Paris review: Interviews, IV. Picador.

Russell, B. D. (2003). Reaching haiku's pedagogical nature. Curriculum Intertext: Place / Language / Pedagogy, 193, 93-102. Retrieved from https://www.jstor.org/stable/42978057

Schlesinger, A. M. (1949). The politics of hope and the bitter heritage. Princeton University Press.

Seemiller, C., \& Grace, M. (2016). Generation z.goes to college. John Wiley \& Sons.

Seybold, P. (2014, June 22). Servants of power: Higher education in an era of corporate control. Truthout. Retrieved from https://truthout.org/articles/servants-of-power-higher-educationin-an-era-of-corporate-control/

Seymour, C. (2020, August 26). Billie Eilish on hope. Vogue. Retrieved from https://www.vogue.com/article/billie-eilish-the-state-of-hope

Shifman, L. (2014a). The cultural logic of photo-based meme genres. Journal of Visual Culture, 13(3), 340-58. https://doi.org/10.1177/1470412914546577

Shifman, L. (2014b). Memes in digital culture. MIT Press.

Shirane, H. (1998). Traces of dreams: Landscape, cultural memory, and the poetry of Basho. Stanford University Press.

Schor, I. (1987). What fear can teach us: Limits and lessons.. In I. Shor \& P. Freire (Eds.), Pedagogy for liberation: Dialogues in transforming education (pp. 57-60). Westport: Bergin \& Garvey.

Schor, I. (1996). When students have power: Negotiating authority in a critical pedagogy. University of Chicago Press.

Spanos, B. (2021, June 17). Billie Eilish and the pursuit of happiness. Rolling Stone. Retrieved from https://www.rollingstone.com/music/music-features/billie-eilish-new-album-happier-thanever-tour-1183156/

Journal of the Scholarship of Teaching and Learning, Vol. 21, No. 4, December 2021. josotl.indiana.edu 
St. Félix, D. (2019, April 26). Billie Eilish and the changing face of pop. The New Yorker. Retrieved from https:/ / www.newyorker.com/culture/cultural-comment/billie-eilish-and-thechanging-face-of-pop

Stopera, D. (2021, January 12). 22 pictures that prove gen $z$ humor is on an entirely different level than millennial humor. BuzzFeed. Retrieved from https://www.buzzfeed.com/daves4/gen-zhumor

Takiguchi, S. (n.d.). The importance of a sense of humour in haiku. New Zealand Poetry Society. Retrieved from https://poetrysociety.org.nz/affiliates/haiku-nz/haiku-poemsarticles/archived-articles/the-importance-of-a-sense-of-humour-in-haiku/

Toulmin, A. (2017, December 14). Memeback: Exploring memes as a feedback mechanism. Medium. Retrieved from https://medium.com/bits-and-giggles/test-43da47d187cd

Visicks. (2020, September 26). TIK TOK MEMES that made my depression laugh [Video file]. YouTube. Retrieved from https://www.youtube.com/watch?v=iShlEkpEB18

Vogel, A. (2013). The dream and the dystopia: Bathetic humor, the beats, and Walt Whitman's idealism. Amerikastudien / American Studies, 58(3), 389-407. Retrieved from https://www.jstor.org/stable/43485897

Vonnegut, K. (1969, 1991). Slaughterhouse-five or the children's crusade: A duty-dance with death. Dell Publishing.

Walen, G. (2020, May 27). Fresh talk: For generation z, humor is our refuge from the coronavirus and everything else. Hartford Courant. Retrieved from https://www.courant.com/opinion/op-ed/hc-op--20200527-eciqkp4tnjhspo66zl62gb5beestory.html

West, C. (2017, September 8). Spiritual blackout, imperial meltdown, prophetic fightback. Convocation Address for Harvard Divinity School. Retrieved from https://hds.harvard.edu/news/2017/09/08/transcript-cornel-wests-2017-convocationaddress \#

Wright, J. (1998). Introduction. In R. Wright, Y. Hakutani, \& R. L. Tener (Eds.), Haiku: The last poems of an American icon (pp. vi-xii). Arcade Publishing.

Yancy, G., \& hooks, b. (2015, December 10). Buddhism, the beats and loving blackness. The New York Times. Retrieved from https://opinionator.blogs.nytimes.com/2015/12/10/bell-hooksbuddhism-the-beats-and-loving-blackness / 